\title{
Protestants, Gender and the Arab Renaissance in Late Ottoman Syria
}

\author{
Deanna Ferree Womack \\ Edinburgh: Edinburgh University Press, 2019. 406 pages.
}

To scholars of the Nahda, that is, the Arab cultural renaissance which unfolded in Egypt and Ottoman Syria over the course of the late nineteenth and early twentieth centuries, the journalist, teacher, and writer Butrus alBustānī is well familiar. However, few might be aware that al-Bustānī was also a committed Protestant Christian involved in building local church structures. Probably even fewer know that his daughter, Alice al-Bustānī, and other members of his extended family were at once important figures within the Syrian Protestant church and central protagonists of the Nahda.

It is the merit of Deanna Womack's meticulously researched and compellingly argued book Protestants, Gender and the Arab Renaissance in Late Ottoman Syria, which is based on her dissertation, that it gives voice to a range of new and hithertho understudied personalities, particularly Syrian women. By creatively using both mission and university archives, and reading against the grain sources produced by Arabic-speaking Christians and international missionaries, Womack highlights the contribution of local Protestants to the Nahda. In doing so, her book makes two major interventions to the field. First, it establishes that Protestantism indeed provided an important motivation for Syrians to become involved in literary, educational, social, and cultural endeavors during that time period. In contrast to earlier research, which labeled figures like al-Bustānī "Christian secularists", Womack demonstrates that religious ideas and debates, expressed in the writings and activism of local Protestants, were crucial components of the Nahda. Second, her book proves that women's contributions were central to spreading its ideas, however much the important presence of women on the ground was often marginalized by both their male counterparts and in later scholarship. By highlighting the agency of Syrian Protestant men and women, Womack pushes back against a portrayal of the Nahda as an allegedly "secular" phenomenon and as a reformist movement mainly carried by men.

In five well-structured and lucidly written chapters, Womack lays out her argument, which is based on extensive archival work in Lebanon, the United States, and the United Kingdom. Following the introduction, which 
establishes the book's time frame, main themes, protagonists, and major arguments, chapter one provides an extensive backdrop for the ensuing discussion. It offers an overview of broader historical development, the entangled histories of 'Western' Christian missions in the wider region, and the growth of local Protestant communities between the 1860 Lebanese civil war and 1915, when the effects of the First World War shifted the focus from literary and cultural activities to relief efforts. While the chapter takes the work of American Presbyterian and British missionaries as a starting point, it already firmly steers the debate away from Western 'influence' and leadership and instead highlights contributions by local Protestant Christians. Syrian Protestantism began to grow from the 1820s onward, mostly through conversions from other Christian communities. Even though numerically, Protestants always remained a small minority, they nevertheless had a significant impact on intellectual developments in the wider region through their educational work and print production. While institutions of higher education, such as the Syrian Protestant College (the predecessor to the American University of Beirut, est. 1866), are relatively well-researched, other educational ventures and forms of cultural and literary production by local Christians have to date been neglected in scholarship. Chapter one also revises earlier scholarship in mission studies by highlighting the complexity of religious identities, cross-connections between different communities, and ongoing patterns of Western paternalism towards local Christians. All of this is based on an analysis of conversion narratives written by Syrian Christians between the 1820s and the 1890s. Although in themselves these narratives are fascinating sources for recovering indigenous voices, they could have been examined more extensively to make a significant contribution to conversion studies as well.

Chapter two ("Publishing the Gospel, Reading the Nahda: Protestant Print Culture in Late Ottoman Syria") sheds light on the work of the American Mission Press (AMP) in Beirut through its printed products, especially its most important periodical al-Nashra al-Usbü'iyya (est. 1863). The bulk of pamphlets, textbooks, children's books, novels, scientific and history books, sermons and periodicals published at the AMP were mainly written and edited by Syrian Protestants, as Womack demonstrates. A survey of their contents shows that just like their Muslim counterparts, they often harked back to a "golden age" of Islamic history, promoted a revival of Arabic literature, popularized alternative forms of Arabic poetry, spread new ideas about educational and social reform, and discussed modern 
science and technology, but they also debated religious topics with other Christians as well as Muslim authors. In contrast to earlier research, which sometimes described the AMP as a mouthpiece of American missionaries, the chapter points out the different (and more positive) attitudes of local Protestant Christians towards Islam, the Prophet Muhammad (115), and Ottoman rule (113). It situates Syrian Protestants firmly within the Nahda's intellectual framework, sharing the same public space and similar concerns with other Nahdawi writers.

Chapters three, four, and five direct the discussion towards the book's main theme: gender, specifically as it shapes forms of paternalism and patriarchy. Paternalism was exerted by American missionaries towards local Christians; patriarchy emanated from American men towards Syrian and American women, but also from Syrian men towards the women of their own communities. These three chapters form the core of the book and supply the reader with a wealth of biographical information on largely unknown Syrian Christians and their activities inside and outside the church, without ever losing sight of the bigger picture.

Chapter three ("A Feminist Awakening? Evangelical Women and the Arab Renaissance") highlights Syrian Protestant women's roles as writers, public speakers, educators, and activists. Whether they composed novels or taught in girls' schools, published on child-rearing or wrote for periodicals, founded charities or gave public speeches, Syrian women were anything but passive 'recipients' of an intellectual movement thought out and led by men. Participants of the 'Protestant women's Nahda' were inspired by their faith, got an education, earned their own income, promoted women's financial and intellectual independence, advocated for marriage equality, commented on morals and manners, explicated religious scriptures, argued against the seclusion of women, battled misogyny, and helped build the Syrian Protestant church by giving sermons and working for their congregation. In sum, Syrian Protestant women not only fully participated in the Nahda, as the chapter demonstrates, but were actually some of its earliest female proponents.

Chapter four ("Ministers and Nahdawi Masculinity: The Beirut Church Controversy") scrutinizes institutional racism and patriarchy exerted by American missionaries, who often cast themselves into a 'fatherly' role towards their Syrian 'children'; depicted Syria as a 'dark' and 'backward' place; and portrayed local converts as immature and incapable of assuming responsibility, all in order to elevate their own contribution and maintain their power. By tracing the contours of the so-called Beirut 
Church Controversy in 1902, in which an anonymous pamphlet criticized the dominance of American Presbyterian missionaries, the chapter makes a significant contribution to Critical Mission Studies. It unveils mechanisms of power and domination that kept Syrian Christians out of decision-making positions and firmly retained control over resources in the hands of Americans. In Womack's own words: “The Syria Mission upheld a patriarchal leadership structure that excluded women from clerical office and high administrative positions, even as it promoted the education of girls and provided opportunities for women to engage publicly in religious work. This was not simply a matter of masculine privilege, however, as American missionary ministers also exercised control over the men of the Syrian Protestant community" (222). The important work done in this chapter, which asks critical questions about racism and inequality within Christian mission ventures, has the potential to prompt similar research into other former mission fields in the Middle East and in South, Southeast, and East Asia.

The fifth and final chapter ("Syrian Women with a Mission: Preaching the Bible and Building the Protestant Church") returns to the theme of gender and subaltern studies by analyzing the role of the so-called 'Biblewomen', local female preachers who often worked in rural settings among illiterate populations and usually outnumbered Syrian men, but were severely underpaid and rarely ever recognized in American missionary reports. By reconstructing their histories, Womack argues for a subtle but significant 'feminization' of the Protestant movement in the region, demonstrating the subversive power of women's presence on the ground. In the absence or even defiance of male authority, Biblewomen gave sermonettes, served as counselors in resolving disputes, interpreted the Bible, and held de facto religious authority among the people they served. Women in such roles were known as mubashshirät in Arabic. They "transcended the socially and religiously constructed boundaries of gender upheld by Syrians and Western missionaries alike" (284), and through their presence they undermined male authority without directly challenging it.

In sum, Protestants, Gender and the Arab Renaissance makes a powerful case for the crucial importance of female contributions to Arab intellectual and social reform movements in the late nineteenth and twentieth centuries, emphasizes the agency of local Christians in contesting 'Western' hegemony while also laying bare the inherent power dynamics in this relationship, and underlines the mobilizing force of religious ideas in 
challenging both local and foreign patriarchy as well as 'Western' paternalism and domination. The book, which is richly illustrated with rare photographs of Syrian men and women, and complemented by a number of useful and meticulously edited indices on Syrian Protestant families, church members, Biblewomen, and Syrian Christian publications, is a must-read for all those interested in the Nahda, modern Middle Eastern history, mission studies, and a global history of gender and religious ideas.

Maria-Magdalena Fuchs

Research Fellow

Leibniz-Zentrum Moderner Orient, Berlin, Germany

doi: 10.35632/ajiss.v37i1-2.705 